\title{
Factors and effects of work-related stress and burnout on the well-being of social workers in the Eastern Cape province, South Africa
}

Author:
Jabulani G. Kheswa' ${ }^{1}$
Affiliation:
'Department of Psychology,
Faculty of Social Sciences and
Humanities, University of
Fort Hare, Alice, South Africa
Corresponding author:
Jabulani Kheswa,
jkheswa@ufh.ac.za
Dates:
Received: 21 Mar. 2019
Accepted: 03 July 2019
Published: 10 Oct. 2019
How to cite this article:
Kheswa, J.G. (2019). Factors
and effects of work-related
stress and burnout on the one or
to read online.
well-being of social workers
in the Eastern Cape province,
South Africa. SA Journal of
Industrial Psychology/SA
Tydskrif vir Bedryfsielkunde,
45(0), a1661. https://doi.org/
10.4102/sajip.v45i0.1661
Copyright:
Co 2019. The Authors.
Licensee: AOSIS. This work
is licensed under the
Creative Commons
Attribution License.

Orientation: Work-related stress and burnout among social workers are on the rise because of extensive workload, job dissatisfaction and exposure to traumatic situations. Therefore, one should determine how they impact the well-being.

Research purpose: This study determined the factors and effects of work-related stress and burnout on the well-being of social workers.

Motivation for the study: An alarming number of social workers show no compassion towards the clients owing to burnout. Therefore, more research is needed for social workers to enhance their purpose and work engagement.

Research approach/design and method: This qualitative study was designed from an interpretivist perspective. Fourteen social workers, aged 35-59 years, from two Department of Social Development and Welfare offices (Alice and King Williams Town) selected through purposive sampling participated in the study. Data were gathered by means of focus group interviews and grounded theory was applied for data analysis.

Main findings: The study results confirmed that social workers attributed their work-related stress to lack of resources such as transport, computers and inadequate emotional support from their supervisors. Thus, they demonstrated impaired personal strength and poor human relations.

Practical/managerial implications: To achieve commitment and optimism, there should be recruitment of new staff and salary increase for social workers.

Contribution/value-add: The study results should provide coping strategies for social workers when faced with secondary traumatic stress.

Keywords: Burnout; Well-Being; Social Workers; Work-related Stress; Coping; Emotional Support; Job Satisfaction; Resources; Trauma.

\section{Introduction}

Social work is the leading profession in terms of experiencing poor physical health, poor job satisfaction and impaired well-being (Graham, Shier, \& Nicholas, 2016) because the work conditions for social workers are unbearable and characterised by stress (Hipp, Beenhardt, \& Allmendingen, 2015). In Zimbabwe, social workers working under stringent circumstances despite being underpaid left the profession for industrialised countries such as Australia, the United Kingdom and New Zealand because the ratio of social workers to children who were dependent on their services (1:49 000) was uneven and detrimental to their well-being (Mugumbate \& Nyanguru, 2013). In Nordic countries, social workers in public sectors expressed job dissatisfaction because of extensive workload and organisational policy (Blomberg, Kallio, Kroll, \& Saarinen, 2015), while in Hong Kong an alarming number of social workers reported working long hours (Vyas \& Luk, 2010). Because social workers should ensure that maltreated children are protected from abusive caregivers and should manage children' court proceedings (Truter, Fouche, \& Theron, 2016; UBS Optimus Foundation, 2016), it is not surprising that a disproportionate number of South African social workers experience secondary traumatic stress. Secondary traumatic stress encompasses reactions originating from coming into contact with conflicted clients in hostile environments, thereby leading to an experience of flashbacks, avoidance and/or intrusive memories (Graham et al., 2016). To prove the intensity of secondary traumatic stress among social workers, adolescent women from child-headed households in the Eastern Cape province, South Africa, during the focus group interviews mentioned that the social workers stopped doing the home visits because they would not endure listening to the painful stories of how at times they 
(adolescent women) would risk their lives by engaging in transactional sex with older men (Kheswa, 2017).

From the eco-social approach, social workers are concerned about the structures of the society and how people relate to their social problems as social work practice is founded on the holistic model (Murty, Sanders, \& Stensland, 2015). Social work refers to an educational discipline that is responsible for bringing social change and development, promoting social cohesion, involving community participation as well as empowering and giving freedom to the people (Van Wyk, 2011). Because social workers generally provide care in health and home settings (Simons \& An, 2015), a majority of them experience work-related stress, thereby leading to poor mental health as a result of burnout. Work-related stress can be described as overwhelming internal (individual) and external (environment) challenges that contribute towards high turnover, lack of positive work engagement and decreasing job satisfaction (Van Wyk, 2011). According to Sonnentag, Pundt and Albrecht (2014), there are five categories of stressors that need attention to avoid a situation where the social workers may experience job dissatisfaction. These categories are:

1. physical stressors (e.g. concerns for safety and security of individuals)

2. task-related stressors (e.g. job density)

3. role stressors (e.g. unclear job description and expectations)

4. social stressors (e.g. poor human relations)

5. career-related stressors (e.g. limited opportunities for development).

It is no wonder that the new qualified South African social workers who went for exchange programmes to countries such as Malaysia and England for placement (i.e. 6 months practical) depicted task-related stressors and career related stressors as attributable to their disengagement because they were immersed in many paperwork and the guidance and support from the supervisors were minimal (Hollis, 2012; Matthew \& Lough, 2017). Some of the contributory factors mentioned by social workers as leading to stress were lack of communication tools, such as telephone or Internet access for reaching out to clients or completion of reports. Such factors may over time result in burnout, which is an extreme emotional exhaustion that takes place when one is unable to fulfil the responsibilities in the workplace (Maslach, 2003; Wagaman, Geiger, Shockley, \& Segal, 2015). Ultimately, such social workers may lose interest in showing compassion to the clients.

Previous South African quantitative studies on burnout at the workplace seemed to have focused on nurses (Khamisa, Peltzer, Ilic, \& Oldenburg, 2017), medical doctors (Rajan \& Engelbrecht, 2018) and educators at the boarding schools (Blew, 2018), all in Gauteng province. In a survey conducted among the final year social work students from one university in South Africa, Le Roux, Steyn and Hall (2018) found that a majority of black students displayed low professional efficacy, vulnerability and emotional burnout as compared to their white counterparts. It is against this background that this qualitative study intends to investigate how work-related stress contributes towards impaired well-being among the social workers in the Eastern Cape province, South Africa.

\section{Research objectives}

The introductory discussion highlights how work-related stress among social workers from different countries contributes to burnout. Maslach, Jackson and Leiter (2014) described burnout as a psychological syndrome that results from chronic interpersonal stressors at workplace and social workers who experience it may feel detached from work and clients, lack a sense of purpose and self-actualisation (Piatkowska, 2014) and develop pessimism (Papathanasiou, 2015). Brinkborg, Michanek, Hesser and Berglund (2011) confirmed that social workers are most likely to experience stress and burnout when they lack resource to execute their duties. In South Africa, various scholars have documented that social workers should be overwhelmed because in ensuring the safety of orphans, child-headed households and families struck by domestic violence, they need to intervene (Kheswa, 2017; McLaren, Steenkamp Feeley, Nyarko, \& Venter, 2018; Meinck, Cluver, Boyes, \& Ndhlovu, 2015). It is reported that of the 18213 social workers registered with the South African Council of Social Work (Jamieson, Sambu \& Mathews, 2017), only 9289 were in the government sector 5 years back, of whom the majority of social workers in South Africa are likely to resign, experience fatigue or be unproductive. This research has therefore been motivated by an alarming number of social workers who are exposed to secondary traumatic stress. Furthermore, the need to conduct a qualitative study among black social workers experiencing burnout would be necessary as the sample in this study have demonstrated impaired purpose in life, lack of motivation, post-traumatic stress disorder, poor immune system and displacement because of the lack of accountability from the managers and insufficient resources.

\section{Potential value-add of the study}

Practically, this study's findings may be of importance to the body of knowledge regarding social workers' well-being, who work under excruciating conditions. Furthermore, from a methodological point of view, this study is of importance because the work-related stress is investigated qualitatively. Participants' reactions to psychological, cognitive and behavioural stressors may assist the minister of Department of Social Development and Welfare to improve the work conditions including incentives for social workers. At the local level, the centre managers should liaise with the government in recommending the fringe benefits for social workers who are multi-skilled. The sequence in this article will be unfolded through highlighting theoretical perspectives on work-related stress and burnout in the 'Literature' section. Then the research methodology will be presented, followed by a discussion on the results of the study. 


\section{Literature}

Christina Maslach introduced the theory of burnout and described job burnout as prolonged response to chronic interpersonal stressors at workplace (Maslach, 1982; Maslach, Schaufeli, \& Leiter, 2001). Closely linked to the theory of burnout is Lazarus and Folkman's coping theory (1985), which states that psychological stress responses may be emotional, behavioural and cognitive when individuals do not cope. Physical stress can manifest in deterioration of body tissues; cause high blood pressure, depression, heart failure, backaches, headaches and fatigue; and contribute towards low sexual libido because of a weak immune system (Bernstein, 2018).

In South Africa, a total of $19 \%$ of social workers who migrated to countries such as New Zealand have led to burnout for those still working in the government sectors and non-profit organisations (NGOs) (Bartley et al., 2016). This is because they are immersed in documentation and paperwork, management of multiple services (e.g. family reunification, psychosocial support and placement) and validation of methods for clients. Furthermore, they should adapt to an increased accountability and practice guidelines (Acker, 2010). Similarly, in Romania, in 2012, there was a deficit of 11000 social workers (Teșliuc, Grigoraș, \& Stănculescu, 2015), while in Namibia, by 2013, there were only 656 employed registered social workers to address the social needs of a population of over 2.1 million (Republic of Namibia, 2013). This shortage of staff has been documented being attributable to chronic stress among social workers.

Considering that the budget made by the South African Department of Social Development for compensation of social workers was at $0.5 \%$ in 2015 and it will remain the same until 2021 (UNICEF, 2018), it is not surprising that the majority of social workers display low level of commitment to the profession, resign and do not flourish. Rautenbach (2015) defines workplace flourishing as an employee's optimal functioning at the workplace coupled with a complete state of mental health. Ajzen and Fishbein (1975) posit that when such a perception precedes attitude, intentions and behaviour, social workers are most likely not to leave their careers. This could be true because Gagne and Deci (2005) noted that when the social workers experience fulfilment, career satisfaction and attach social identity to their profession, they lead a heathy lifestyle and for longer duration.

The lack of funding in the Department of Social Welfare and Development has been documented as contributing to stress among social workers because it hinders them to implement interventions targeted at vulnerable people (Chiwara \& Lombard, 2017). For example, in South Africa, which is known for the disproportionate number of people living with HIV pandemic (Van Heerden et al. 2017), owing to insufficient number of state vehicles to transport social workers to reach the people in the rural areas, the majority end up relapsing or not adhering to the antiretroviral treatment. This results in the social workers compromising the ethical commitment to social justice and human rights (International Federation of Social Workers [IFSW], 2014).

Figley (2002) pioneered the concept of compassion fatigue, which is described as the secondary traumatic stress and refers to the emotions and behaviour by social workers when helping the clients, and may be manifested in the demonstration of aloofness, coldness, depersonalisation and lack of interest in the organisational goals and values (Compassion Fatigue Awareness Project, 2015). Social workers who experience secondary traumatic stress following contact sessions with the clients tend to report flashbacks, avoidance and intrusive memories (Piatkowska, 2014). Depersonalisation refers to an experience of psychological distancing from interpersonal relationships, in which social workers show no regard for the clients' human dignity (Le Roux et al. 2018). One way to depersonalise themselves from clients could be absenteeism from work without reporting to their supervisors or applying for leave frequently. Owing to an inability to cope with future stressors at work, Van Breda (2018) depicted that poor mental health hinders the effectiveness among social workers; thus, they demonstrate hopelessness and aloofness towards the clients.

\section{Research design Research approach}

According to Lincoln and Guba (2005), a research paradigm is guided by three key concepts: ontology (definition of legitimate knowledge), epistemology (investigation of the truth) and methodology (knowledge enquiry). The researcher followed a qualitative approach, which is epistemological and methodological in nature, to allow for interpretation. As suggested by Creswell (2003), the purpose of qualitative approach is to explain a particular phenomenon and not to make generalisations.

\section{Research strategy}

In this study, two focus group interviews consisting of 14 social workers from the Department of Social Welfare and Development were conducted.

\section{Research setting and sampling}

This study was conducted at the boardrooms of the two Department of Social Development and Welfare (i.e. Zwelitsha location and Alice) offices of the Eastern Cape province, South Africa. The purposive sampling is defined as a method that is deliberately an effort of gaining representation of sample by including the groups in the probable area (Creswell, 2003; Creswell \& Creswell, 2017). It is important to note that the managers did not get involved in selecting the participants. Instead, the researcher sent an invitation to the participants via email for participation. In Alice location, seven participants (four women and three men), aged 28-59 years, were sampled. In Zwelitsha location, seven participants (three women and four men), aged $25-53$ years, were sampled. All the contacted participants in 
both locations agreed to participate voluntarily in the study and none of them withdrew. The focus group interviews which lasted $1 \mathrm{~h} 30 \mathrm{~min}$ each were conducted over two consecutive days in separate settings to avoid fatigue and bias. The questions asked in both settings were the same. The researcher identified the themes after prolonging the seven participants from two different locations to achieve data saturation. Conducting a qualitative research with small samples builds rapport between the researcher and participants, and allowed the researcher to deeply explore the phenomenon as interpreted by participants in their own specific context (Creswell, 2003; Engel \& Schutt, 2014). According to Lincoln and Guba (2005), such an inductive approach stimulates the likelihood of reassigning findings to similar contexts.

The criteria for selecting the sample included registration with the South African Council of Social Workers. Some of the participants were married, divorced and single. Participants also occupied different ranks and levels (grades). In this study, five of the participants were married, while seven were single as opposed to only two who indicated to have divorced. Of the 14 participants, eight had bachelor's degrees in Social Work (SW), two had master's degrees (SW), one had a master's degree and postgraduate qualifications and the other three had bachelor's degrees in SW and certificates related to their profession. Table 1 provides a summary profile of the research participants at the time of data collection.

\section{Data gathering}

Qualitative methods of data collection, such as observations and interviewing, are preferred by researchers working with interpretive paradigms (Creswell, 2003). For this study, the semistructured interviews were employed as the main method of data collection. An interview guide was prepared prior to data collection and assisted in time-saving because it explored and defined areas that had to be addressed. Owing to the flexibility of this approach, participants elaborated during probing (Gill, Stewart, Treasure, \& Chadwick, 2008). Examples of the questions asked include the following:

- What job-related challenges hinder your professional efficiency?

- How have you been coping with clients who experience domestic violence?

- How do you handle situations where you should remove maltreated children from their caregivers?

- What form of emotional support do you get from your immediate supervisors and/or managers?

- How do you cope with trauma?

The focus group interviews were conducted over 2 days and lasted for $1 \mathrm{~h} 30 \mathrm{~min}$ each.

\section{Recording of data}

Prior to the focus group interviews, permission was requested to audio-tape the participants' responses. Digital recordings were transcribed immediately after the two interviews were concluded, as Creswell (2003) recommends that transcription should happen as soon as possible to facilitate data analysis. A professional transcriber was employed to enhance the trustworthiness of the study.

\section{Data analysis}

The grounded theory approach was used to analyse the data. Three steps of coding - open coding, axial coding and selective coding - were followed (De Vos, Strydom, Fouche, \& Delport, 2011). During open coding, the researcher named and categorised the data into smaller concepts. During axial coding, connections between categories were identified to develop main themes from the data and sub-categories (Engel \& Schult, 2014). Selective coding refers to the main process or the core category, systematically relating to each other categories, confirming those relationships and filling in categories that need further refinement (De Vos et al., 2011). The researcher analysed the data until the data had been theoretically saturated, well established and validated.

TABLE 1: Biographical information of the participants.

\begin{tabular}{|c|c|c|c|c|c|c|c|}
\hline Participant & $\begin{array}{l}\text { Age in } \\
\text { years }\end{array}$ & Marital status & Gender & Qualifications & $\begin{array}{l}\text { Years of service } \\
\text { in work }\end{array}$ & Place of work & Position at work \\
\hline P1 & 35 & Single & $\mathrm{F}$ & Master's degree SW) & 12 & Alice & Social worker \\
\hline P 2 & 39 & Single & M & Bachelor's degree SW) & 10 & Alice & Social worker \\
\hline P 4 & 41 & Married & M & Bachelor's degree SW) & 8 & Alice & Social worker \\
\hline P 5 & 59 & Married & $\mathrm{F}$ & Bachelor's degree SW) and EAP Certificate & 24 & Alice & Senior social worker \\
\hline P 6 & 47 & Divorced & $\mathrm{F}$ & Bachelor's degree SW) and HIV/AIDS certificate & 15 & Alice & Social worker \\
\hline P 8 & 42 & Divorced & $\mathrm{F}$ & Bachelor's degree SW) and Programme in Monitoring and Evaluation & 9 & Zwelitsha & Social worker \\
\hline P9 & 44 & Single & $\mathrm{F}$ & Master's degree SW) and Certificate in Debriefing & 16 & Zwelitsha & Social worker \\
\hline P 10 & 40 & Single & M & Bachelor's degree SW) & 15 & Zwelitsha & Social worker \\
\hline P 11 & 30 & Single & M & Bachelor's degree SW) & 6 & Zwelitsha & Social worker \\
\hline P 12 & 52 & Married & M & Bachelor's degree SW) & 12 & Zwelitsha & Senior social worker \\
\hline P 13 & 25 & Single & M & Bachelor's degree SW) & 2 & Zwelitsha & Social worker \\
\hline P 14 & 53 & Married & $\mathrm{F}$ & Bachelor's degree SW) & 27 & Zwelitsha & Senior social worker \\
\hline
\end{tabular}

EAP, employee assistance programme; SW, social worker. 


\section{Trustworthiness}

Trustworthiness involves establishing credibility, dependability, confirmability and transferability. To establish credibility, the participants were engaged in a prolonged discussion about work-related stress and its consequences as suggested by Connelly (2016). Regarding dependability, Willig and Rogers (2017) suggest that the researchers should ask themselves a question: how dependable are the results? Conformability guarantees that the results, conclusion and the recommendations are supported by data and that there is an agreement between the interpretation and the actual evidence (Brink, Van der Walt \& Rensburg, 2006). The researcher supported his findings by comparing them to the existing literature. Transferability refers to the probability that the study findings have meaning to others in similar situations. The expectation for determining whether the findings fit or are transferable rests with potential users of the findings and not with the researchers (De Vos et al., 2011).

\section{Reporting}

In reporting of findings, the researcher's interpretations should be substantiated with the exact words 'verbatim' from the empirical study and assimilated with relevant theories as suggested by Creswell (2013).

\section{Findings}

To avoid bias when reporting findings, Ritchie, Lewis, Nicholls and Ormston (2013) opine that the explanations and conclusions to be arrived at should be generated from, and grounded in, the data. In this study, eight themes emerged. Thematic analysis is defined as a meticulous process of identifying, analysing and reporting themes that emerge from a qualitative study (Maziriri, Madinga, \& Lose, 2017). Thematic analysis is regarded as the 'foundational method for qualitative analysis' and was chosen to formally exchange the analytical process given its suitability to the exploratory nature of the research (Maziriri et al., 2017). The major advantage of thematic analysis is that it is a logical process that allows the researcher to scrutinise interview transcripts comprehensively and glean all possible themes (Maziriri et al., 2017). The following framework indicates the main themes identified in the data sources. Each theme will be discussed individually, followed by substantiating quotes. Interpreted data will be compared with the existing literature.

\section{Theme 1: Lack of resources in the Department of Social Development and Welfare}

More than a quarter of participants from both centres indicated that their professional efficiency is compromised because of a lack facilities. They indicated that they delay in attending families and children who should be rescued from hostile environments as a result of shortage of cars. For example, they cited:

There is a shortage of resources in our office. For example, here we are 21 staff and there is only one car which is now not working. (Participant 1, 35 years old, female)
When we have to go for visit, we would have to wait for the other person because there is only one car. (Participant 4 , 41 years old, male)

We are unable to visit clients in need of counselling because there is only one car for almost 12 villages. (Participant 13, 25 years old, female)

The need for repairing equipment was also raised by participants as they struggle to compile monthly reports because of computers which do not function, as evident in the following extracts:

We have computers here but they are not working, and at the end of the month you are expected to submit your reports. (Participant 5, 59 years old, female)

The system that the department is using has failed us. We have a few of the resources here but they are not working. For instance, we have computers here but they are not working; if it is working there is no internet and some of our work requires us to capture our records for report filing but we cannot do that and that makes us to look as if we are inefficient. (Participant 6, 47 years old, female)

\section{Theme 2: Lack of accountability}

From the responses of the participants, it is evident that the social workers do not get support from their managers, especially in Alice:

Everyone do as they please here because of lack of observation by management. There was a time here when one that our colleagues was not paid for almost a year and when enquiring this they told him that he was not in the system and was not recognised as an employee in the department. Furthermore, other departments get incentives but here we are just working and we have been waiting for our benefits until now. (Participant 3, 38 years old, female)

This lack of accountability from the managers could be demotivating because the participants were aware that their colleagues from other departments had been given incentives:

We have been waiting for a long time here for money that we were promised but it has not reached us. We see people from other departments being rewarded for their work but to us... nothing. (Participant 1, 35 years old, female)

\section{Theme 3: Impaired purpose in life}

By gender, both female and male participants expressed feelings of regret for having pursued social work as there is no personal growth and recognition for their dedication. Their responses indicated impaired sense of purpose in life because they kept on referring to their friends who lead successful careers in other department:

I won't lie to you, there are times when I regret doing this degree because even when you have experience in many areas such as clinical social work and restorative justice, when posts are being advertised, they are being filled by people from outside. Hence I say majority of us have lost courage and drink alcohol to forget their problems. (Participant 10, 40 years old, male) 
A female participant who holds a masters' degree in SW concurred by saying:

I do not even consider myself as someone who possesses a Master's degree in social work because of how we are treated and the conditions we work under. We love doing our job and we are passionate about it, but there is no improvement in our salaries. My friends who work as teachers get promotion and some are principals as we speak. (Participant 1, 35 years old, female)

According to Jessen (2015), rewarding is important for the employee as it helps them to be firm, productive and achieve their goals. Thus, the absence of this leads to poor performance and more turnovers.

\section{Theme 4: Job satisfaction}

Regarding job satisfaction, there was a strong affirmation among the participants that they were not happy and they highlighted the lack of extrinsic motivation. Gagne and Deci's (2005) Self-determination Theory (SDT) states that any factor at the workplace that satisfies human needs, such as competence, relatedness and autonomy, is likely to enhance intrinsic motivation. On the other hand, performance contingent rewards have the propensity to improve extrinsic motivation (Zhu, Gardner, \& Chen, 2018). The responses reflect the lack of extrinsic motivation:

I just don't know any more. When I was still at school I thought that I would be busy everyday helping people, but when coming to the real world it's a different story. I am even tired of coming to work because I know that I will just sit and do nothing. (Participant 2, 39 years old, male)

Every month we have to do reports and score ourselves, and that month I did campaigns and even went an extra mile but I was given a low score and my supervisor could not stand for me and fight for a higher score. (Participant 7, 28 years old, male)

Everyone likes to be praised when they have done well in what they were doing. Lack of recognition discourages a person and that is where we would feel tired of what we do. Just little incentives make a difference. (Participant 14, 53 years old, female)

\section{Theme 5: Post-traumatic stress disorder}

The study results indicate that there are participants who experienced post-traumatic stress disorder when they provide counselling. Despite the 20 years of service, Participant 12 cited:

The work that we do affect us psychologically because at times, we are supposed to be emotionally strong for rape victims and parents whose children got killed while in prison. It is impossible for you to run away from the emotional pain although I suffer from insomnia and lately, my hypertension has gone high. (Participant 12, 52 years old, male)

Similarly, a female participant, who has been a social worker since she was 24 years old, mentioned that there is no safety at work and witnessing a scene where someone was shot has built anxiety. She has been quoted as follows:

There was an incident recently, where one of our colleagues was attacked here at work by someone unknown, even until this day I fear for my life. Whenever I watch television and there are killings, I just tremble because we could have been severely injured since that man was having a gun. Next year I will be retiring and I have no plans of extending it. (Participant 5, 59 years old, female)

Another male participant witnessed the domestic violence of elderly couple and he did not know how to intervene. He narrated as follows:

I could not believe my eyes when a 65 year old man severely beat his wife who was accusing him of adultery. He tackled her until she fell on the floor. (Participant 13, 25 years old, male)

Post-traumatic stress disorder falls under anxiety disorders and refers to a pattern of negative reactions following a traumatic event, commonly involving re-experiencing the event in the form of nightmares (Bernstein, 2016). These findings correspond with the study conducted in Finland, in which social workers who participated in a longitudinal study reported a burnout that manifested in a decline in overall physical health and respiratory infections (Kim, Ji, \& Kao, 2011).

\section{Theme 6: Displacement}

Owing to overwhelming workload experienced by social workers, it emerged that some participants have harboured anger and they would vent it out to innocent individuals. Such behaviour is called displacement. According to Sigmund Freud, father of psychoanalytic theory (Freud \& Bonaparte, 1954), displacement is a defence mechanism in which an individual may deflect an impulse from its original target to a less threatening one. For example, a female participant expressed the following when asked about their coping strategies regarding documentation when parents apply for Child Support Grant:

There are times I would throw my frustrations at my boyfriend and we would fight because I feel at times that he does not understand where I'm coming from but eventually we would be fine. Talking about things that bothers us helps in a relationship and also understanding one another boosts it. (Participant 9, 44 years old, female)

\section{Theme 7: Debriefing for social workers}

There were mixed feelings expressed by participants regarding debriefing. Debriefing is defined as reviewing accounts of what occurred and how an individual has reacted psychologically, emotionally and behaviourally to a traumatic situation (Miller, 2004). Some participants mentioned that the workshops were for debriefing. Participant 5 continued to emphasise that the Department of Social Development and Welfare does not care about their well-being:

When one of our colleagues was attacked, nothing was done. How do they expect us to work effectively when we know that people can go in and out of here as they please because there are no security guards at the entrance? I always fear for my life here. (Participant 5, 59 years old, female)

Another female participant expressed a wish that the workshops they attend(ed) should be more about debriefing as they do not cope: 
I sometimes wish that these workshops that we go to would focus more on us on how we cope with different cases because I have a concern that we as social workers have nowhere to go when things get tough in the field. (Participant 8, 42 years old, female)

Another participant highlighted that despite having informed his manager about his bereavement, no support of any kind came forth:

I recently lost my younger brother in a tragic way and that affected my work performance. The department did nothing, only my colleagues supported me through that time and even booked me a psychiatrist in East London because I was not coping. (Participant 11, 30 years old, male)

\section{Theme 8: Religion and human relations}

It was clear from the participants that family support, human relations and religion play critical roles in their mental health. For example, the following extracts attest to this fact:

Every day we have services at church, so that is one thing that helps me to deal with everyday issues. I have also established prayer meetings with some colleagues. We do pray for strength and our souls have begun finding peace. (Participant 12, 52 years old, male)

As you can see that I'm married, my husband is very supportive and understanding I do not want to lie. When I get home feeling overwhelmed because of work issues, he understands and we talk about it, he encourages me and it's all gone. (Participant 3, 38 years old, female)

Protective factors such as the family support and church have been documented as buffers against stress (Fuentes-Peláez, Balsells, Fernández, Vaquero, \& Amorós, 2016; Killian, Hernandez-Wolfe, Engstrom, \& Gangsei, 2017). Drawing from Bronfenbrenner's ecological systems theory (FuentesPeláez et al., 2016) and classical work by Frankl (1959), individuals may perform to their optimal level and show their capabilities when their significant others help them find meaning and purpose in what they do. These findings are congruent to an online survey that took place in 2015 among more than 6000 social workers from 13 states in the United States of America, where Seinreich, Straussner and Steen (2018) found $82 \%$ of the respondents having indicated job satisfaction as opposed to stress. In other words, when there are meaningful relationships among social workers and the work environment is conducive (Hom, Lee, Shaw, \& Hausknecht, 2017), even those who were contemplating to resign tend to remain and fit the organisational values to be part of their social identity (Tajfel \& Turner, 1986).

\section{Ethical considerations}

\section{Entrée and establishing research roles}

Permission to conduct the study was obtained from Govan Mbeki Research and Development Centre (GMRDC), a unit at the University of Fort Hare, which ensures that any research study involving people as subjects should adhere to ethical principles, respecting the confidentiality, informed consent and privacy of the participants. Then, the letters detailing the purpose of the study were sent to the managers at the Department of Social Development and Welfare (Zwelitsha location and Alice) and focus group interviews with seven social workers from each location were requested. The researcher assigned numbers P1-P7 for participants in Alice and P8-P14 for participants in Zwelitsha to ensure anonymity. The roles of the researchers were explained during the focus group interviews.

\section{Discussion}

From the findings of this study, it is clear that when a person has given himself or herself to his or her work, they may find purpose and resilience. For example, a male participant who used his car to attend the meetings and workshops demonstrates passion and dedication. Furthermore, there are participants who highlighted the importance of religion and family support as a form of coping in the face of adversity. In other words, such support and church services enable their resiliency effect. Participants showed that the only support that they get is from their families, mostly from their husbands - those who are married. The support that they get from home makes them to be able to face the challenges of the next day. This reveals that family support is vital when you are someone who deals with people who will also look to you for support, because at work you have to be professional and be confidential. Research by Grant and Kinman (2011) revealed that support from family as an environmental factor is a major predictor of resilience to stress in the future. From social welfare perspective, the term 'resilience' is used to describe a process in which a social worker demonstrates a psychological rebound and a healthy functioning in the face of adversity (Theron, 2016; Ungar, 2012; Van Breda, 2018). This is what Antonovsky (1979) refers to as 'salutogenic' as some of the social workers would remain healthy while others become ill despite being exposed to the same stress.

However, it is evident that some of the participants' health has deteriorated because of workload and low salaries. Some of the participants got accepted at the hospitals because of depression and there were some reports of hypertension. Brinkborg et al. (2011) confirmed that social workers working under difficult circumstances with high job demands and limited resources are to a point faced with psychological effects of experiencing stress and burnout. This includes symptoms of emotional exhaustion and low levels of job satisfaction. These negative consequences therefore are related to feeling undervalued at work with high demands of work and little control. Job dissatisfaction is what is left for the participants. They no longer enjoy their work and some of them are thinking of finding another job in a different field whereas others are thinking of moving to a different department. As there are participants who mentioned hopelessness, it could be concluded that they have developed a pessimistic attitude towards work. According to Wagaman et al. (2015), hopelessness is caused by bad past experiences and also seeing that there is no hope even for the present. That causes a person to feel anxious about the future. The situation that is always there for the participants makes 
them to conclude that nothing will ever change. Thus, they cannot see any future in their career. Their circumstances make them lose hope for the department and for themselves. Another possibility could be a decision to leave social work profession because they are not recognised. Smith (2009) and Mavimbela (2015) are of the opinion that managers should hire new staff and try to value social workers by paying them performance bonuses.

It is evident that the social workers are floundering (i.e. experience state of mental illness); thus, they reverted to alcohol abuse. The implications of drinking alcohol by social workers could bear negative consequences on their occupational functioning because they may be absent and end up being addicted. Furthermore, alcohol abuse may give rise to risk sexual behaviour owing to impaired judgement. Therefore, an Employee Assistance Programme (EAP) should be considered for social workers to protect their overall wellbeing because work environments with high psychological distress could induce family conflicts as suggested by Zheng, Molineux, Mirshekary and Scarparo (2015). The benefits of EAP include assertiveness training, building of self-esteem, coping strategies, teamwork and greater job satisfaction (Richmond, Pampel, Wood, \& Nunes, 2017).

Because the social workers have been relating to the traumatic experiences, the use of empathy is necessary. Even in tragedies where the individuals experience helplessness and have suicidal ideations, they are expected to empathise and return to work immediately and attend to the next client(s) as if they have not been exposed to trauma (Cacciatore, Carlson, Michaelis, Klinek, \& Steffan, 2011). Given the implications of secondary traumatic stress, it is important for the social workers to get debriefing. Kruse, Argueta, Lopez and Nair (2015) claim that the absence of support to patients leads to negative attitude towards their caregivers and also to their full recovery. In contrast, Wairire and Zani (2015) stated that Kenya is one of the countries that have showed support to the social workers, working to eradicate poverty in the country with resources that would help the communities. Interventions included educational support for the children. Also, social support is said to be the variable that buffers against work-related stress.

\section{Conclusion Implications}

Based on the findings, it is most likely that the majority of social workers will resign unless the government improves the working conditions (human resources) and increases the salaries according to their qualifications and experience. There should be two cars in each centre to visit the clients, especially in remote areas. Most importantly, when the Department of Social Development and Welfare fails to revise the job descriptions of the social workers and assign them based on their expertise, their offices would always be congested and those in need of their services, such as indigent families, would continue to suffer. Finally, more cases of burnout would be inevitable.

\section{Limitations}

Although this study yielded valuable information on how to improve the work conditions of social workers, there are limitations that impacted the study. The study was restricted to two locations. Although the group was homogeneous in terms of race and career, the difference was in the number of years in the profession as well as their marital status. Another potential factor that might have triggered the results is that the interviewer is the former lecturer of some of the participants. Another limitation has to do with the small sample size. With the utilisation of a small sample size, one cannot decisively sum up the findings, even though various questions were utilised as a part of a drive to decide how extensive the sample was. In future research, a larger population including a large sample of social workers is ought to be examined.

\section{Recommendation for future research}

Although the findings cannot be transferred to other work environments, they prove meaningful for the purpose of the study. Research replicating the present study in other similar contexts will help to broaden the knowledge of social workers and their work-related stress. Finally, quantitative study would cover many participants whose experiences may influence the South African government to improve the lives of social workers.

Work engagement is a state of employees' cognitive-affective well-being (Warr, 2013) and it is characterised by high activation, pleasure, fulfilment and drive to work (Mäkikangas et al., 2015). Similar to thriving, work engagement could potentially enhance competitiveness, psychological wellbeing among the social workers while acting as a buffer against burnout (Hoole \& Bonnema, 2015; Porath, Spreitzer, Gibson \& Garnett, 2012). To achieve the above, there is also a need for team-building sessions for social workers to learn to support one another. As this research was qualitative in nature, future research can centre around triangulation techniques to stay away from this bias. Other scholars can use the themes or factors (e.g. impaired purpose in life, lack of motivation, post-traumatic stress disorder, poor immune system and displacement because of lack of accountability from the managers and lack of resources) identified in this study to create a conceptual model and to test it quantitatively. Moreover, comparative studies between the results of this study and those obtained from other emerging economies could also be considered in the future. This could lead to other thought-provoking insights that were not captured in the present study.

\section{Acknowledgements}

The author thanks the Department of Social Development for the support provided and the study participants for their participation. 


\section{Competing interests}

The author declares that they have no financial or personal relationships which may have inappropriately influenced them in writing this article.

\section{Author's contributions}

The author conducted all the interviews and performed the write-up of the article, and is the sole contributor.

\section{Funding information}

This research received no specific grant from any funding agency in the public, commercial, or not-for-profit sectors.

\section{Data availability statement}

Data sharing is not applicable to this article as no new data were created or analysed in this study.

\section{Disclaimer}

The views and opinions expressed in this article are those of the authors and do not necessarily reflect the official policy or position of any affiliated agency of the authors.

\section{References}

Acker, G.M. (2010). How social workers cope with managed care. Administration in Social Work, 34(5), 405-422. https://doi.org/10.1080/03643107.2010.518125

Ajzen, I., \& Fishbein, M., (1975). A Bayesian analysis of attribution processes. Psychological Bulletin, 82(2), 261-277. https://doi.org/10.1037/h0076477

Antonovsky, A. (1979). Health, stress, and coping. San Francisco, CA: Jossey Bass.

Bartley, A., Beddoe, L., Duke, J., Fouché, C., Harington, P., \& Shah, R. (2016). Crossing borders: Key features of migrant social workers in New Zealand. Aotearoa New Zealand Social Work, 23(3), 16-30. https://doi.org/10.11157/anzswj-vol23iss 3id157

Bernstein, D. (2018). Essentials of psychology (pp. 490-537). (7th edn.). Australia: Cengage Learning.

Blew, M.B.B. (2018). The association between burnout and demographic characteristics of educators living in boarding schools. Masters dissertation. Pretoria: University of Pretoria.

Blomberg, H., Kallio, J., Kroll, C., \& Saarinen, A. (2015). Job stress among social workers: Determinants and attitude effects in the Nordic Countries. The British Journal of Social Work, 45(7), 2089-2105. https://doi.org/10.1093/bjsw/bcu038

Brink, H., Van der Walt, C., \& Van Rensburg, G. (2006). Fundamentals of research methodology for health care professionals. Cape Town: Juta and Company Ltd.

Brinkborg, H., Michanek, J., Hesser, H., \& Berglund, G. (2011). Acceptance and commitment therapy for the treatment of stress among social workers: A randomized controlled trial. Behaviour Research and Therapy, 49(6-7), 389-398.

Cacciatore, J., Carlson, B., Michaelis, E., Klimek, B., \& Steffan, S. (2011). Crisis intervention by social workers in fire departments: An innovative role for social workers. Social Work, 56(1), 81-88. https://doi.org/10.1093/sw/56.1.81

Chiwara, P., \& Lombard, A. (2017). The challenge to promote social and economic equality in Namibia through social work. Social Work, 53(4), 563-578. https://doi. org/10.15270/53-4-598

Compassion Fatigue Awareness Project (CFAP). (2015). Recognizing compassion fatigue. Retrieved from www.compassionfatigue.org.

Connelly, L.M. (2016). Trustworthiness in qualitative research. Medsurg Nursing, 25(6), 435-437.

Creswell, J.W. (2003). Research design: Qualitative, quantitative and mixed method approaches (2nd edn., pp. 9-11). CA: Sage, A framework for design.

Creswell, J.W. (2013). Educational research: Planning, conducting, and evaluating Brantford: W. Ross MacDonald School Resource Services Library.

Creswell, J.W., \& Creswell, J.D. (2017). Research design: Qualitative, quantitative, and mixed methods approaches. CA: Sage.

De Vos, A.S., Delport, C.S.L., Fouché, C.B., \& Strydom, H. (2011). Research at grass roots: A primer for the social science and human professions. Pretoria: Van Schaik Publishers.
Engel, R.J., \& Schutt, R.K. (2014). Fundamentals of social work research. London: Sage.

Fuentes-Peláez, N., Balsells, M.À., Fernández, J., Vaquero, E., \& Amorós, P. (2016). The social support in kinship foster care: A way to enhance resilience. Child \& Family Social Work, 21(4), 581-590. https://doi.org/10.1111/cfs.12182

Figley, C.R. (2002). Compassion fatigue: Psychotherapist's chronic lack of self-care. Journal of Clinical Psychology, 58(11), 1433-1441. https://doi.org/10.1002/ jclp.10090Figley

Frankl, V. (1959). Man's search for meaning. Boston, MA: Beacon Press.

Freud, S., \& Bonaparte, P.M., (1954). The origins of psychoanalysis (vol. 216). London: Imago.

Gagné, M., \& Deci, E.L. (2005). Self-determination theory and work motivation. Journal of Organizational Behavior, 26, 331-362. https://doi.org/10.1002/ job.322

Gill, P., Stewart, K., Treasure, E., \& Chadwick, B. (2008). Methods of data collection in qualitative research: Interviews and focus groups. British Dental Journal, 204(6), 291. https://doi.org/10.1038/bdj.2008.192

Graham, J.R., Shier, M.L., \& Nicholas, D. (2016). Workplace congruence and occupational outcomes among social service workers. British Journal of Social Work, 46(4), 1096-1114. https://doi.org/10.1093/bjsw/bcu153

Grant, K., \& Kinman, G. (2011). Enhancing well-being in social work students: Building resilience in the next generation. Social Work Education, 31(5), 1-17. https://doi. org/10.1080/02615479.2011.590931

Hipp, L., Bernhardt, J., \& Allmendingen, J. (2015). Institutions and the prevalence of nonstandard employment. Socio-Economic Review, 12(2), 351-377. https://doi. org/10.1093/ser/mwv002

Hollis, C.J. (2012). Exploring international internships in social work education, Unpublished Master's thesis, California State University, Chico, CA.

Hom, P.W., Lee, T.W., Shaw, J.D., \& Hausknecht, J.P. (2017). One hundred years of employee turnover theory and research. Journal of Applied Psychology, 102(3), 530-545. https://doi.org/10.1037/apl000103

Hoole, C., \& Bonnema, J. (2015). Work engagement and meaningful work across generational cohorts. SA Journal of Human Resource Management, 13(1), 1-11. https://doi.org/10.4102/sajhrm.v13i1.681

International Federation of Social Workers (IFSW) (2014). 'Africa'. Retrieved from https://ifsw.org/tag/africa/

Jamieson, L., Sambu, W., \& Mathews, S. (2017). Out of Harm's Way? Tracking child abuse cases through the child protection system at five selected sites in South Africa-Research Report. Cape Town: Children's Institute.

Jessen, J.T. (2015). Job satisfaction and social rewards in the social services. Journal of Comparative Social Work, 5(1), 15-31. https://doi.org/10.31265/jcsw.v5i1.51

Khamisa, N., Peltzer, K., Ilic, D., \& Oldenburg, B. (2017). Effect of personal and work stress on burnout, job satisfaction and general health of hospital nurses in South Africa. Health SA Gesondheid, 22(1), 252-258. https://doi.org/10.1016/j.hsag. 2016.10.001

Kheswa, J.G. (2017). The impact of dysfunctional families and sexual abuse on the psychological well-being of adolescent females, Eastern Cape, South Africa. Journal of Sociology and Social Welfare, XLIV(2), 161-176.

Killian, K., Hernandez-Wolfe, P., Engstrom, D., \& Gangsei, D. (2017). Development of the Vicarious Resilience Scale (VRS): A measure of positive effects of working with trauma survivors. Psychological Trauma: Theory, Research, Practice, and Policy, 9(1), 23. https://doi.org/10.1037/tra0000199

Kim, H., Ji, J., \& Kao, D. (2011). Burnout and physical health among social workers: A three- year longitudinal study. Social Work, 56, 258-268. https://doi.org/ 10.1093/sw/56.3.258

Kruse, C.S., Argueta, D.A., Lopez, L., \& Nair, A. (2015). Patient and provider attitudes toward the use of patient portals for the management of chronic disease: A systematic review. Journal of Medical Internet Research, 17(2), e40. https://doi org/10.2196/jmir.3703

Lazarus, R.S., \& Folkman, S. (1984). Stress, appraisal and coping. New York: Springer Publishing Company.

Le Roux, L., Steyn, F., \& Hall, B. (2018). Burnout and engagement in fourth-year social work students: Why we should be concerned. Social Work, 54(2), 179-193. https://doi.org/10.15270/54-2-632

Lincoln, Y.S., \& Guba, E.G. (2005). Paradigms and perspectives in contention. In N. Denzin \& Y. Lincoln (Eds.), Handbook of qualitative research (2nd edn., pp. 163-188). Thousand Oaks, CA: Sage.

Mäkikangas, A., Rantanen, J., Bakker, A.B., Kinnunen, M.L., Pulkkinen, L., \& Kokko, K. (2015). The circumplex model of occupational well-being: Its relation with personality. Journal for Person-Oriented Research, 1, 115-129. https://doi.org/ 10.17505/jpor.2015.13

Maslach, C. (1982). Burnout: The cost of caring. New York: Prentice Hall.

Maslach, C. (2003). Job burnout: New directions in research and intervention. Current Directions in Psychological Science, 12, 189-192. https://doi.org/10.1111/1467. 8721.01258

Maslach, C., Jackson, S., \& Leiter, M. (2014). Burnout inventory manual (4th edn.). Menlo Park, CA: Mind Garden, Inc.

Maslach, C., Schaufeli, W.B., \& Leiter, M.P. (2001). Job burnout. Annual Review of Psychology, 52(1), 397-422. https://doi.org/10.1146/annurev.psych.52.1.397 
Matthew, L.E., \& Lough, B.J. (2017). Challenges social work students encounter in international field placements and recommendations for responsible management. Journal of Social Work Education, 53(1), 18-36. https://doi.org/10. management. Journal of Social

Mavimbela, J. (2015). Social work as a scarce skill: Exploring the views of socia workers regarding the retention strategies used by the human resource managers workers regarding the retention strategies used by the human resource managers to retain social workers within the Department of Social De
dissertation. Johannesburg: University of Witwatersrand.

Maziriri, E.T., Madinga, W., \& Lose, T. (2017). Entrepreneurial barriers that are confronted by Entrepreneurs living with physical disabilities: A thematic analysis. Journal of Economics and Behavioral Studies, 9(1), 27-45. https://doi.org/ 10.22610/jebs.v9i1.1555

McLaren, S., Steenkamp, L., Feeley, A., Nyarko, J., \& Venter, D. (2018). Food insecurity, social welfare and low birth weight: Implications for childhood malnutrition in an urban Eastern Cape Province township. South African Journal of Child Health, 12(3), 95-99.

Meinck, F., Cluver, L.D., Boyes, M.E., \& Ndhlovu, L.D. (2015). Risk and protective factors for physical and emotional abuse victimisation amongst vulnerable
children in South Africa. Child Abuse Review, 24(3), 182-197. https://doi.org/ children in South

Miller, J. (2004). Critical incident debriefing and social work: Expanding the frame. Journal of Social Service Research, 30(2), 7-25. https://doi.org/10.1300/J079v 30n02_02

Mugumbate, J., \& Nyanguru, A. (2013). Exploring African philosophy: The value of ubuntu in social work. African Journal of Social Work, 3(1), 82-100.

Murty, S.A., Sanders, S., \& Stensland, M. (2015). End-of-life care as a field of practice in the social work curriculum. Journal of Social Work End Life Palliative Care, 11(1) 11-26. https://doi.org/10.1080/15524256.2015.1021071

Papathanasiou, I.V. (2015). Work-related mental health consequences: Implications of burnout on mental health status among health care providers. Acta Informatica Medica, 23(1), 22-28. https://doi.org/10.5455/aim.2015.23.22-28

Piatkowska, J.M. (2014). The relationship between mindfulness and burnout among master of Social Work students. PhD thesis. Portland: Portland State University.

Porath, C., Spreitzer, G., Gibson, C., \& Garnett, F.G. (2012). Thriving at work: Toward its measurement, construct validation, and theoretical refinement. Journal of Organizational Behavior, 33(2), 250-275. https://doi.org/10.1002/job.756

Rajan, S., \& Engelbrecht, A. (2018). A cross-sectional survey of burnout amongst doctors in a cohort of public sector emergency centres in Gauteng, South Africa. African Journal of Emergency Medicine, 8(3), 95-99. https://doi.org/10.1016/j. afjem.2018.04.001

Rautenbach, C. (2015). Flourishing of employees in a fast moving consumable goods environment. Doctoral thesis. Vanderbijlpark: University of North West. Retrieved environment. Doctoral thesis. Vanderbijlpar
from https://hdl.handle.net/10394/17030

Republic of Namibia. (2013). Social development policy: Situational analysis on socia development in Namibia version 5, 3rd draft, March 2013. Windhoek: Ministry of Social Development and Welfare.

Richmond, M.K., Pampel, F.C., Wood, R.C., \& Nunes, A.P. (2017). The impact of employee assistance services on workplace outcomes: Results of a prospective quasi-experimental study. Journal of Occupational Health Psychology, 22(2), 170-179. https://doi.org/10.1037/ocp0000018

Ritchie, J., Lewis, J., Nicholls, C.M., \& Ormston, R. (Eds.). (2013). Qualitative research practice: A guide for social science students and researchers. London: Sage.

Seinreich, E., Straussner, S.L.A., \& Steen, J. (2018). The work experience of socia workers: Factors impacting compassion satisfaction and workplace stress. Journal of Social Service Research, 1-17. https://doi.org/10.1080/01488376.201 8.1528491

Simons, K., \& An, S. (2015). Job satisfaction among gerontological social workers in Ontario, Canada. Journal of Gerontological Social Work, 58(6), 547-571. https:// doi.org/10.1080/01634372.2015.1042129
Smith, J.L. (2009). Twelve reasons why employees leave organisation. USA: S-Square Enterprises.

Sonnentag, S., Pundt, A., \& Albrecht, A.G. (2014). Temporal perspectives on job stress. In A.J. Shipp \& Y. Fried (Vol. Eds.), Time and work (vol. 1). Montana State: Taylor and Francis.

Tajfel, H., \& Turner, J.C. (1986). The social identity theory of intergroup behaviour. In S Worchel \& L.W. Austin (Eds.), Psychology of intergroup relations (pp.7-24). Chicago, IL: Nelson-Hall.

Teșliuc, E., Grigoraș, V., \& Stănculescu, M. (Eds.). (2015). Studiu de fundamentare pentru Strategia naţională privind incluziunea socială şi reducerea sărăciei 2015-2020. Retrieved from http://documents.worldbank.org/curated/en/46505 $1467995789896 / p d f / 103191-W P-P 147269-B o x 394856 B-P U B L I C-B a c k g r o u n d-$ Study-ROMANIAN.pdf.

Theron, L.C. (2016). Toward a culturally and contextually sensitive understanding of resilience: Privileging the voices of black, South African young people. Journal of Adolescent Research, 31, 635-670. https://doi.org/10.1177/0743558415600072

Truter, E., Fouche, A., \& Theron, L.C. (2016). The resilience of child protection social workers: Are they at risk and if so, how do they adjust? A systematic metasynthesis. British Journal of Social Work, 47(3), 846-863. https://doi.org/10.1093/ bjsw/bcw048

UBS Optimus Foundation. (2016). Technical report (2016): Sexual victimisation of children in South Africa Final report of the Optimus Foundation Study: South Africa, June. Zurich, Switzerland. Retrieved from www.optimusstudy.org.

Ungar, M. (2012). Social ecologies and their contribution to resilience. In M. Ungar (Ed.). The social ecology of resilience: $A$ handbook of theory and practice (pp. 13-31). New York: Springer.

UNICEF. (2018). 2018/19 Social Development Budget Brief South Africa. Retrieved from pp. 13-31. https://www.unicef.org/southafrica/SAF_ resources_budgetbrief_socialdevelopment2018.pdf.

Van Breda, A.D. (2018). A critical review of resilience theory and its relevance for social work. Social Work, 54(1), 1-18. https://doi.org/10.15270/54-1-611

van Heerden, A., Harris, D.M., van Rooyen, H., Barnabas, R.V., Ramanathan, N., Ngcobo, N., ... Comulada, W.S. (2017). Perceived mHealth barriers and benefits for home-based HIV testing and counseling and other care: Qualitative findings from health officials, community health workers, and persons living with HIV in South Africa. Social Science \& Medicine, 183, 97-105. https://doi.org/10.1016/j. socscimed.2017.04.046

Van Wyk, C. (2011). Beroepstres en streshantering by maatskaplike werkers wat betrokke is by intervensie met seksueel misbruikte kinders. PhD thesis. Stellenbosch Universiteit van Stellenbosch.

Vyas, L., \& Luk, S. (2010). Frazzled care for social workers in Hong Kong: Job stress circumstances and consequences. International Social Work, 54(6), 832-851. https://doi.org/10.1177/0020872810382684

Wagaman, M.A., Geiger, J.M., Shockley, C., \& Segal, E.A. (2015). The role of empathy in burnout, compassion satisfaction, and secondary traumatic stress among social in burnout, compassion satisfaction, and secondary traumatic stress among
workers. Social Work, 60(3), 201-209. https://doi.org/10.1093/sw/swv014

Wairire, G.G., \& Zani, A.P. (2015). The role of social work in poverty reduction and realization of MDGs in Kenya. Nairobi: University of Nairobi Press.

Warr, P. (2013). How to think about and measure psychological well-being. In R.R Sinclair, M. Wang, \& L.E. Tetrick (Eds.), Research methods in occupational health psychology (pp. 76-90). London: Routledge.

Willig, C., \& Rogers, W.S. (Eds.). (2017). The SAGE handbook of qualitative research in psychology. London: Sage.

Zheng, C., Molineux, J., Mirshekary, S., \& Scarparo, S. (2015). Developing individual and organisational work-life balance strategies to improve employee health and wellbeing. Employee Relations, 37(3), 354-379. https://doi.org/10.1108/ER-10 2013-0142

Zhu, Y.Q., Gardner, D.G., \& Chen, H.G. (2018). Relationships between work team climate, individual motivation, and creativity. Journal of Management, 44(5), 2094-2115. https://doi.org/10.1177/0149206316638161 